VERSLAG VAN DE DERDE ALGEMEENE VERGADERING VAN HET KONINKLIJK INSTITUUT VOOR DE TAAL- LAND- EN VOLKENKUNDE VAN NEÊRLANDSCH INDIË, GEHOUDEN TE DELFT, DEN 30STEx APRIL 1853, DES vOORMIDDAGS TE 11 UUR.

De President opent de Vergadering met eene korte toespraak. De Secretaris leest de Notulen der vorige Vergadering en het Verslag van den staat en de werkzaamheden des Instituuts gedurende het afgeloopen jaar 1852/53. (Zie Bijlage B).

De President doet, namens het Bestuur, twee voorstellen, die de Vergadering na eenige discussic aanneemt: het eene, om, even als in de vorige algemeene Vergadering was toegestaan, nog voor een jaar de magtiging te verleenen tot het toelaten van nieuwe leden zonder stemming, het andere, om, indien geene bijzondere redenen het tegendeel wenschelijk maken, de aanstaande algemeene Vergadering in October uit te stellen.

De Huishoudelijke Bepalingen ondergaan eene kleine verandering en worden daarna op nieuw voor een jaar vastgesteld.

De drie aftredende leden van het Bestuur, de HH. Leemans, ROORDA en sIMONS, worden herkozen.

De Vergadering vraagt en verkrïgt de toestemming van den President om de toespraak, waarmede deze bijeenkomst geopend werd, in het Tijdschrift op te nemen (zie Bijlage A), en brengt haren dank aan de inzenders van stukken in de Bïdragen.

Niemand meer het woord verlangende wordt de Vergadering gesloten. 
INLEIDING DER ALGEMEENE VERGADERING VAN 30 APRIL 1853.

\section{Mijne heeren!}

Het door u op den $24^{\text {sten }}$ April des verleden jaars gekozen bestuur, heef mij andermaal tot zijnen voorzitter benoemd. Het is als zoodanig dat mij ten tweeden maal, de eer te beurt valt, mij, in uwe algemeene vergadering op den voorzitterstoel te mogen nederzetten, en $\mathrm{u}$ welkom te mogen heeter aan deze plaats.

Uit het overzigt hetwelk $\mathrm{u}$, krachtens art. 35 van het reglement, zal wor den medegedeeld, zal u blijken dat onze gemeenschap met Nederlandsc Indië is aangeknoopt. De naamlijst van hen, die dáár tot het lidmaatscha] zijn toegetreden, zal $\mathrm{u}$ doen zien dat het Instituut thans onder zijne Indi sche leden telt, mannen van erkende bekwaamheid en veeljarige ondervin ding. Met ons zult gij $\mathrm{u}$ dan ook verheugen in het vooruitzigt dat van dáár gewigtige bijdragen zullen worden ontvangen, voor het Tijdschrift voor de werken van het Institunt.

De verwezenlijking van dat vooruitzigt zou echter kunnen verschoven worden, wanneer onze medearbeiders zich eene volmaaktheid ten doel stel den, die in zaken van Land-, Taal en Volkenkennis, veelal slechts lang zaam en na een gerekt onderzoek wordt genaderd. Dit deed mij dan oo reeds in onze vorige bijeenkomst de verklaring afleggen, dat ook onvolledig bijdragen zouden welkom zijn, hetzij over zelfgekozene onderwerpen, hetz als antwoorden op de van wege het Instituut gedane vragen. Ik gelo uw aller gevoelen nit te drukken, wanneer ik van deze plaats, en als eev gepaste inleiding tot de werkzaamheden van den dag, op nieuw al 
leden van het Instituut, zoo hier als in Indië, aanspoor om zich niet door een overmatig streven naar volmaaktheid van het inzenden van opstellen te laten terughouden. Alles, ook dat hetwelk uit den aard van het onderwerp niet dadelijk tot volledigheid kan worden gebragt, zal welkom zijn. Het zal onzen voorraad bouwstoffen vermeerderen, en aanleiding kunnen geven tot nader onderzoek en onderlinge vergelijking. "Niemand (ik herhaal hier de woorden een jaar geleden uitgesproken) "niemand verschoone "zich dan van het medearbeiderschap. Slechts door de vereenigde pogin"gen van allen, kan het Instituut zich op eene eervolle wijze handhaven "onder de nuttige instellingen van Nederland."

Kondigde ik $\mathrm{u}$, in mijne vorige toespraak, aan, dat de toen pas uit Indië teruggekeerde Gouverneur-Generaal rochussen zich onder de leden donateurs van het Institunt had doen insehrijven, zijn opvolger in het hoog bewind van Nederlandsch Indië, de Heer Duymaer van twist, heeft dit almede gedaan, onder het uiten van verzekeringen, even vleijend voor het Instituut, als bemoedigend voor deszelfs toekomst.

Die toekomst, M. H. ligt overigens in onze handen! Bij den vasten wil om het doel, hetwelk wij ons hebben gesteld, te bereiken, zal onze nog jeugdige inrigting zegevieren over de hinderpalen aan alle nieuwe ondernemingen eigen, en die ook reeds door het Instituut op zijnen weg zijn ontmoet.

Ik verklaar de derde algemeene Vergadering van het Instituut te zijn geopend en verzoek den Secretaris de notulen der tweede bijeenkomst aan de goedkeuring te onderwerpen. 
OVERZigT VAN DEN STAAT EN DE WERKZAaMHEDEN VAN HET KON. INSTITUUT VOOR DE TAAL- LAND- EN VOLKENKUNDE VAN NEÊRLANDSCH INDIË, GEDURENDE HET JAAR 1852/53.

\section{MIJNE HEEREN!}

De tak die ik heden ter voldoening aan Art. 35 van het reglement vervullen heb, is, zoo als dit gewoonlijk het geval is, van een gemengdet aard. Veel heb ik mede te deelen, wat goed is - veel wat wij ander zouden wenschen.

Zoo het bestuur zich aan den eenen kant te verblijden heeft over de ge reede toetreding van zijne Excellentie den Gouverneur-Generaal van Ne derlandsch Indië, Mr. A. J. DUYMAER van TwIST, als lid donateur, en var ongeveer zeventig ambtenaren, officieren en ingezetenen aldaar, tot he lidmaatschap des Instituuts; voorts over de pogingen van de Heeret Mr. A. PRINs, algemeen Secretaris en J. c. TEEngs, lid der factorij var de Nederlandsche Handelmaatschappij, om de belangen der instelling te be vorderen, - en eindelijk over den ijver waarmede door enkelen stof word geleverd voor onze Bijdragen en Werken; - het bestuur betreurt het aan den anderen kant dat deze medewerking zich dusver nog niet heeft uitgestrekt tot de Oost-Indische bezittingen. Mogt het eerstvolgende verslag van den staat en de werkzaamheden onzer inrigting kunnen melding maken van eene gewenschte verandering, in dit opzigt, en van veel talrijker toetre dingen van ginds, dan wij thans ter uwer kennis kunnen brengen, en waartoe onder de ambtenaren en ingezetenen, van allen stand, nog ruime gelegenheid bestaat!

Het is billijk te erkennen dat op deze uitkomst omstandigheden hebbe» invloed gehad, gedeeltelijk van eenen geheel toevalligen aard, waardoor de 